\title{
Assessment of Social Vulnerability to Flood in Urban Côte d'Ivoire Using the MOVE Framework
}

\author{
Malan Ketcha Armand Kablan ${ }^{1, *}$, Kouassi Dongo ${ }^{1,2}$ and Mamadou Coulibaly ${ }^{3}$ \\ 1 Unité de Formation et de Recherche des Sciences de la Terre et des Ressources Minières, Université Félix \\ Houphouët Boigny, 01 BP V34 Abidjan 01, Côte d'Ivoire; kdongo8@gmail.com or kouassi.dongo@csrs.ci \\ 2 Centre Suisse de Recherches Scientifiques en Côte d'Ivoire (CSRS), Abidjan, \\ 01 BP 1303 Abidjan, Côte d'Ivoire \\ 3 Department of Geography and Urban Planning, University of Wisconsin Oshkosh, 800 Algoma Blvd, \\ Oshkosh, WI 54901, USA; coulibalym@uwosh.edu \\ * Correspondence: kablan.malan@yahoo.fr; Tel.: +225-0830-9085
}

Academic Editor: Athanasios Loukas

Received: 29 November 2016; Accepted: 18 April 2017; Published: 21 April 2017

\begin{abstract}
Coupled with poor urban development, the increasing urban population of many Sub-Saharan African countries is subject to recurrent severe flooding episodes. In response to these flood events, while the focus is often put on slums and precarious urban settings, the social implications of these floods affect a variety of social classes. Presenting a case study of Cocody, a district of Abidjan, Côte d'Ivoire, known to have the country's highest number of flood-impacted people, this paper evaluates the social vulnerability of urban Côte d'Ivoire to flooding using the MOVE framework. The MOVE framework (Method for the Improvement of Vulnerability Assessment in Europe) has successfully been used in European contexts to assess social vulnerability of urban areas to geo-environmental disasters such floods. It helped assess the major factors involved in the social vulnerability to urban flooding and to have a good appreciation of the spatial distribution of areas that are vulnerable to urban flood. By taking this framework to the local context, relevant indicators were developed and GIS applications were used to assess spatially the relative social vulnerability of Cocody sub-districts to urban flooding. The results revealed that many sub-districts of Cocody are highly vulnerable to urban floods. Exposure and susceptibility are components that are found to have high influence on vulnerability to flood hazard in the district of Cocody. Their respective indicators need to be addressed properly in order to increase residents' resilience to urban flooding. The MOVE theoretical framework can be applied in Africa by contextualizing the vulnerability by using local indicators.
\end{abstract}

Keywords: climate change; Côte d'Ivoire; MOVE framework; social vulnerability assessment; urban flooding

\section{Background}

Flooding occurs when water accumulates in places that are not normally submerged. In urban areas, they are usually the consequence of extreme rainfall, which creates an excess of runoff that is above the capacity of the drainage systems [1]. With more than half of the global population living in urban areas, these phenomena are becoming an increasing public concern [2]. Their occurrences and amplitudes will increase due to climate change and the increasing urban population [3].

Urban floods are one of the most common and widely distributed natural risks for life and property worldwide $[4,5]$. It has been reported that in the last decade, urban floods have impacted most parts of the world including the USA, Europe, Asia, and Africa [6-12]. Flooding occurs in the least developed nations as well as in the most developed countries [13]. In the developed world, urban floods are often related to hazards, such as climate change, storm surge, flash floods, and consecutive heavy precipitations. However, in addition to the highlighted causes that prevail in the developed world, 
flooding in developing countries is also due to the precariousness of the drainage system, the lack of maintenance of the infrastructures and the mismanagement of household wastes [14-16]. Indeed, factors influencing flood risks differ from one area to another depending upon local environmental context and management strategies. Hence, assessing vulnerability to flood hazard is an essential step towards effective risk reduction, as it helps identify local factors that contribute to the vulnerability and to measure their significance.

Although Africa is the least urbanized region in the world, its urban inhabitants are expected to double by 2030 [17]. As a result, there is a dilemma between community planning and ways of obtaining sustainable urban development. Thus, urban flooding is likely to worsen, and the continent is known to be more vulnerable to climate change, due to extreme poverty and wars that delay progress $[18,19]$. In Sub-Saharan Africa where about $72 \%$ of urban inhabitants live in slums [17], the consequences of urban flooding could be worsened by the lack of adequate protection infrastructures [15]. Unplanned growth and development in such areas usually results in flooding when the flood protection structures fail under extreme hydrological weather conditions [20]. Studies have reported that West Africa is particularly subject to urban floods [21-23]. The region was struck in 2007 by heavy precipitation causing widespread regional flooding that affected a total of 792,676 people and caused 210 deaths [24].

Abidjan, the economic capital of Côte d'Ivoire, offers a prime example of this phenomenon of urban flooding. In that city, every rainy season is characterized by its number of deaths and the extent of its damages. According to the Office for the Coordination of Humanitarian Affairs (OCHA), from 2009 to 2014, an average of 13 flood-related deaths per year were recorded in Abidjan [25]. In these conditions, flood vulnerability assessment is important not only because flooding inflicts harm to humans, but also for proper urban planning and adaptation to climate change [2]. A good knowledge of flood-prone areas, the level of vulnerability of an urban area to flooding and the socio-economic, environmental and physical factors that play a major role in shaping the hazard, could be an important step toward improving the resilience of growing African cities like Abidjan, Côte d'Ivoire. Although flood hazards are natural phenomena, the vulnerability of an area to flooding is a combination of socio-economic and environmental factors that vary spatially from one place to another.

During the last few decades, many studies on vulnerability to flooding have been carried out in Côte d'Ivoire. For the most part, these studies focused on slums and assessed the socioeconomic impacts of flood on the affected community [26,27], without considering the factors that contributed the most to people's vulnerability. Most of the studies [7] failed to incorporate social aspects in the definition of vulnerability to flooding. Thus, through the case study of Cocody, a district of Abidjan, Côte d'Ivoire (in Sub-Saharan West Africa), this study aims to close the gap by providing an assessment of the social vulnerability of an urban area to flooding. For that purpose, some local indicators are evaluated with the MOVE (Method for the Improvement of Vulnerability in Europe) framework, which integrates various indicators including environmental and societal aspects.

\section{The Concept of Vulnerability}

Vulnerability determines how people will be affected and where they are spatially located [21,28]. The concept of vulnerability is approached from different disciplines and professional fields such as academia, disaster management agencies, climate change community and agencies [29]. While there is no universal definition [30], the definition varies so widely that, in interdisciplinary context, the term becomes almost useless without further specification [31]. According to the Intergovernmental Panel on Climate Change (IPCC) [32], vulnerability is defined as "the degree to which a system is susceptible to, and unable to cope with, adverse effects of climate change, including climate variability and extremes". Concerning climate change vulnerability, it refers to the state of susceptibility to harm from exposure to climate hazards, and the ability of a unit of analysis to cope with, and recover from, such exposure as well as manage incremental and long-term change in climate [33]. For some authors [9], vulnerability is the extent of harm that can be expected under certain conditions of exposure, susceptibility and resilience. Though many definitions exist, the concept of vulnerability in this study considers the 
approach provided by Welle and collaborators [34]. For them, it is the likelihood of injury, loss, and disruption of livelihood caused by an extreme event and/or by the obstacles in recovering from the disturbance that a system can potentially cause. By this logic, vulnerability has specific spatial, socio-economic-demographic, cultural and institutional contexts that impose challenges to research on social vulnerability to flooding [35].

Vulnerability to flooding, therefore, has many dimensions such as social, geographical, economic and political that influence how floods affect inhabitants in varying ways and with different intensities [29]. Many approaches in assessing vulnerability to geo-environmental disasters exist [36]. These approaches are reflected in various analytical concepts and models, which serve as guides for developing indicators for measuring that type of vulnerability [37]. Many models have been used to approach the broader concept of vulnerability and have been well described elsewhere [38]. For instance, the Conceptual Framework to Identify Disaster Risk [29] defines risk as a function of hazard, exposure, vulnerability and capacities. Since vulnerability is also social, this framework appears incomplete as it excludes exposure and capacity from vulnerability [38]. Bohle's Double Structure of Vulnerability, however, recognizes exposure and coping capacities as determinants of vulnerability but excludes sensitivity, which addresses the impact side of the hazard [38]. The Framework for Vulnerability Analysis in Sustainability Science (SUST Model), on the contrary, includes exposure, sensitivity and resilience in the definition of vulnerability [38,39]. Moreover, it examines vulnerability within the linked human-environment context [38,39]. Therefore, it appears to be a good model for assessing vulnerability. However, it should be critically considered, as it includes impacts under the resilience part of vulnerability [38]. The MOVE (Method for the Improvement of Vulnerability in Europe) framework was developed to provide an improved conceptualization of the multi-faceted nature of vulnerability [40] and is applicable both in the domain of disaster risk reduction and climate change adaptation. In this view, it incorporates key causal factors such as exposure, susceptibility, and lack of resilience in the definition of vulnerability. Moreover, in the MOVE framework, vulnerability can be assessed along different thematic dimensions such as physical, social, ecological, economic, cultural and institutional [40,41]. It appears, therefore, to be more relevant than the previous ones in assessing social vulnerability to natural hazards, thus has been considered in this study.

\section{Study Site}

The district of Cocody in Abidjan, Côte d'Ivoire was chosen as the study site because of the paradox expressed by the fact that it is a high social standing district (a prestigious district where most government officials reside) with a relatively large number of flood-affected people. It also encompasses several slums and some poor residential areas such as Anono, M'Badon and Blokauss (Figure 1). This high social standing district records the highest number of threatened individuals during flooding events in Abidjan. In fact, according to the Office for the Coordination of Humanitarian Affairs (OCHA) [25], more than 40,000 individuals (50\%) are threatened by this hazard in Cocody. Cocody is supposed to be one of the best-planned and most luxurious districts of Abidjan, and it is characterized by its beautiful landscape. Most of its accommodations and amenities are expensive. With an area of $144.59 \mathrm{~km}^{2}$, Cocody is the second largest district of Abidjan after Yopougon. According to the 2014 national census, its population is 447,000 (10.17\% of Abidjan's population) [42]. Cocody is located in the eastern side of the city of Abidjan between latitudes $5^{\circ} 19^{\prime}$ and $5^{\circ} 27^{\prime} \mathrm{N}$, and longitudes $3^{\circ} 54^{\prime}$ and $4^{\circ} 1^{\prime} \mathrm{W}$. It is bordered in the north by the district of Abobo, in the south by the Ebrié lagoon, in the west by the district of Adjamé and in the east by the town of Bingerville (Figure 1). The climate of Cocody is characteristic of what prevails along the entire Gulf of Guinea in West Africa, with four seasons: two dry seasons (December to March and August to September) and two rainy seasons (April to July and October to November). The temperature in Cocody varies throughout the year. The high maximum temperature arises in March with an average temperature of $27.4{ }^{\circ} \mathrm{C}$, while the low minimum temperature occurs in August with an average temperature of $24.2^{\circ} \mathrm{C}$. Rainfall in Cocody also varies throughout the year with two peaks. The first peak is reached in June during the long rainy 
season with a total monthly precipitation of approximately $550 \mathrm{~mm}$. The second peak is reached in October with a total monthly precipitation of $150 \mathrm{~mm}$. In fact, rainfalls in this region of Africa occur with the advent of the West African Monsoon, which is governed by the air flow of the Intertropical Convergent Zone (ITCZ) [43,44].

It is important to note that although it is situated by the coast of the Atlantic Ocean, there is no coastal flood issue related to the city of Abidjan. Thus, the study site, which is well inland, is absolutely not concerned with coastal flooding.

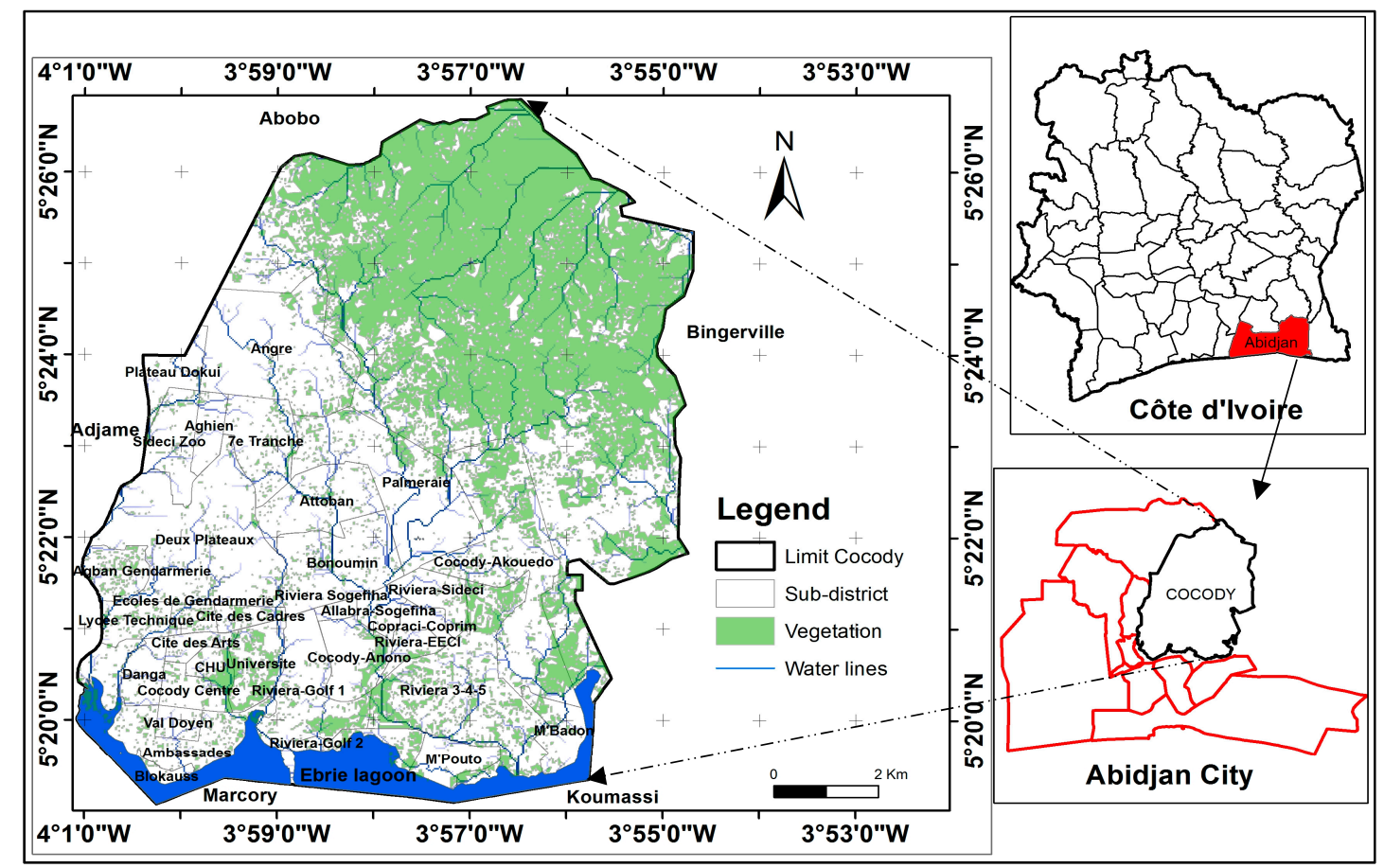

Figure 1. Localization of the district of Cocody.

\section{Methods}

The methodology used in this study is well in line with the goal of the study which is the assessment of the vulnerability of the district of Cocody to urban flooding. It consists essentially of the selection, acquisition and aggregation of the key indicators, followed by a vulnerability assessment that is based on the MOVE framework. A comprehensive description of the MOVE framework is also provided.

\subsection{Data Used}

Data used in this study came from various sources, both primary and secondary. The primary data were mostly concern data obtained from field study (geographical survey and household survey). The geographical survey was conducted during the major rainy season in June 2015. It was thus possible to describe the current state of environmental parameters that contribute to flooding and impact the lives of the populations. Information related to socio-environmental problems was collected in all the sub-district areas of Cocody. The measured parameter for this study was the number of unplanned waste deposits per district area. As for household survey, the data were obtained from 584 households selected randomly for interview across the district. The method used was a personal interview at the respondent's residence. There, the interviewer helped the interviewee complete the questionnaire [45]. As a variety of social classes were involved in the study, this technique was critically important, especially where respondents showed a low level of literacy. It was adopted in order to reflect fairness in the random selection of households. The questionnaire was administrated to the heads of household or their representatives. Nevertheless, we ensured that all respondents were at 
least 18 years old. The initial part of the investigation was geared toward general information on the household (household size, children under five and elderly above 65, number of workers and insured people). It then measured their impressions of flash floods and finally assessed their experiences with floods as well as their coping capacities in relation to sanitation deficits. The parameters for this study included the literacy rate, the frequency of household waste collection and the percentage of insured people. As flooding leads to both health impacts (e.g., cholera and typhoid) and property damages, the term "insured people", in this study, relates to flood insurance and, unlike the way it is in most western countries, it takes into account both health insurance and full-coverage property insurance. The altitude data were extracted from Aster DEM (with a $30 \mathrm{~m}$ resolution) using spatial analysis tools in ArcGIS.

The secondary data concern the vertical permeability of the soil, the extent of flooded areas and population (population density, percentage of children, elders, women and unemployment). The vertical permeability data were obtained using the soil map provided by the Laboratory for Building and Public Work (LBTP). The inhabited flooded areas were extracted by simple digitalization, with ArcGIS, of the OCHA 2014 map describing the flood-prone areas of Abidjan. It was thereafter confirmed and validated during the geographical survey. Vegetation cover was extracted from a LandSat 8 satellite image using the maximum likelihood tools in ArcGIS. Population data were collected from the National Standard Bureau (INS) and concerned the 2014 national census.

\subsection{The MOVE Framework}

The MOVE framework, which was developed to improve vulnerability assessment in Europe, is seen as part of risk evaluation and risk management in the context of disaster risk management (DRM) and climate change adaptation (CCA) as it fulfils a need for standards and guidance in estimating vulnerability as the critical component of risk [41]. It is a thinking tool to guide systematic assessments of vulnerability and to provide a basis for comparative indicators and criteria development to assess key factors and various dimensions of vulnerability [40]. Within the MOVE framework, vulnerability is defined as a degree of susceptibility or fragility of elements, systems or communities, including their capacity to cope under hazardous conditions. Vulnerability is tied to natural and built environmental degradation at the urban level and to gradual climate change. It is therefore seen, from a social viewpoint, as a lack or deficit of sustainability [46]. Human systems and the environment are dependent on one another [47]. In fact, unplanned urbanization often exposes the inhabitants to urban floods. This fact is therefore seen as a lack of resilience. The conceptual MOVE framework (Figure 2) is not hazard-dependent, but recognizes hazards, which can be natural or socio-natural, with society, as represented at international-, national-, sub-national- or local scales, being part of the environment. Both elements, hazards and society, coexist and have constant interactions.

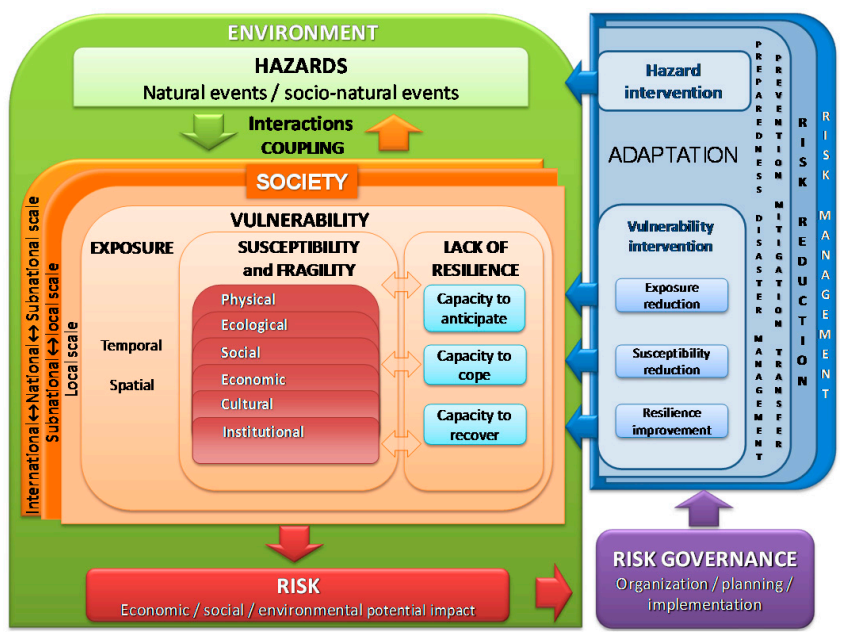

Figure 2. MOVE framework (source: [40]). 
The MOVE framework better fits the objectives defined, since the data that are necessary for the framework are available and easily accessible in the study area. Indeed, in this research, all the indicators considered, related to exposure, susceptibility and resilience, are covered by the MOVE framework. Following this framework, our approach involves statistical analysis, the development of composite indices and the use of Geographic Information Systems (GIS). Thus, even though the approach used in the study is well specified, the vulnerability is mostly displayed using GIS [48-50].

\subsection{Indicator Selection}

The method presented in this study uses the MOVE framework as a reference tool to assess vulnerability. Elaborated in the context of natural hazard research and adaptation to climate change [49], the MOVE framework and its principles have been well described elsewhere [40,46]. In this study, the MOVE framework key factors are defined as follows:

- Exposure (E). It describes the extent to which an area that is subject to an assessment falls within the geographical range of a hazard event [40]. It was defined geographically (in space) as the social and material context, as represented by people, and ecosystem. In this study, it was measured by the number of people per Cocody sub-district area, differently exposed to flood due to their location; and as the socio-environmental factors that aggravate the intensity of the hazard. Exposure is calculated by considering the density of the population per district area (E1), the topography of the considered sub-district (E2), the vertical permeability of the soil (E3), and the percentage of the sub-district area affected by flood hazard (E4).

- Susceptibility (S) describes the predisposition of elements at risk (social and ecological) to suffering harm resulting from the levels of fragility of settlements, disadvantageous conditions and relative weaknesses [40]. The age and health conditions of the population, followed by human behaviors and practices that determine socio-cultural factors, are the main drivers that shape susceptibility to flood [51]. Children under 5 years, the elderly, and women are considered to be the groups most susceptible to harm in the case of flood events. Based on these findings, the following indicators were chosen as representative: the number of children under 5 years, elderly above 65 years, and women per sub-district area; and the number of unplanned waste deposits and the frequency of waste collection per sub-district.

- Lack of resilience (LoR) describes the limitations of access to and the mobilization of resources in the socio-ecological system and the incapacity of that system to respond by absorbing the impact [51]. During flood events, people are mostly affected due to the fact that they did not understand or perceive the warning system correctly. Thus, literacy rate plays an important role in the coping capacity of residents [35]. Affected communities become more resilient to flood when they are able to recover from the hazard. The recovery process presumes the availability of sufficient means and risk transfer tools. It seems, therefore, that the illiteracy rate, number of uninsured people and unemployment rate are good indicators for lack of resilience for a given area. The composite indicator for LoR is then computed by considering the illiteracy rate, the percentage of people uninsured and unemployed per sub-district.

The explanation and references of each selected indicator are presented in Table 1.

Table 1. List and explanation of each selected indicator.

\begin{tabular}{|c|c|c|c|}
\hline Components & $\mathbf{N}^{\circ}$ & Indicators & Explanations \\
\hline \multirow{4}{*}{ Exposure } & E1 & $\begin{array}{l}\text { Population density } \\
\left(\text { inhbts } / \mathrm{km}^{2} \text { ) }\right.\end{array}$ & The higher the population, the higher the exposure [52]. \\
\hline & E2 & Elevation (m) & The lower the elevation, the higher the flood exposure [53]. \\
\hline & E3 & Vertical permeability $(\mathrm{m} / \mathrm{s} 2)$ & $\begin{array}{l}\text { The higher the vertical permeability, the higher the } \\
\text { infiltration and the less exposed the area is to flood [26]. }\end{array}$ \\
\hline & $\mathrm{E} 4$ & $\begin{array}{l}\text { Flooded areas } \\
\text { per sub-district }(\%)\end{array}$ & $\begin{array}{l}\text { The larger the flood inhabited areas, the more people } \\
\text { exposed [54]. }\end{array}$ \\
\hline
\end{tabular}


Table 1. Cont.

\begin{tabular}{|c|c|c|c|}
\hline Components & $\mathbf{N}^{\circ}$ & Indicators & Explanations \\
\hline \multirow{6}{*}{ Susceptibility } & S1 & Children under $5(\%)$ & Fragile health and difficulty for evacuation process [35]. \\
\hline & S2 & Elderly above $65(\%)$ & Fragile health and difficulty for evacuation process [35]. \\
\hline & S3 & $\begin{array}{l}\text { Vegetation cover per } \\
\text { sub-district (\%) }\end{array}$ & $\begin{array}{l}\text { Denser vegetation cover reduces susceptibility of an area } \\
\text { to flood [53]. }\end{array}$ \\
\hline & S4 & Women $(\%)$ & $\begin{array}{l}\text { The higher the number, the higher the susceptibility of } \\
\text { affected people }[35,53] \text {. }\end{array}$ \\
\hline & S5 & $\begin{array}{l}\text { Waste collection } \\
\text { (number of day/week) }\end{array}$ & $\begin{array}{l}\text { The lower the frequency, the higher the susceptibility to } \\
\text { block drainage system, the higher the risk of flood. }\end{array}$ \\
\hline & S6 & $\begin{array}{l}\text { Unplanned waste deposits } \\
\text { (number) }\end{array}$ & $\begin{array}{l}\text { Unplanned waste deposit leads to clogged drainage } \\
\text { systems and increased of flood occurrence [16]. }\end{array}$ \\
\hline \multirow{3}{*}{$\begin{array}{l}\text { Lack of } \\
\text { Resilience }\end{array}$} & LoR1 & Literacy rate $(\%)$ & $\begin{array}{l}\text { The higher the rate, the higher the capacity to understand } \\
\text { early warning systems [35]. }\end{array}$ \\
\hline & LoR2 & Number of people insured (\%) & Insurance implies risk transfer [2]. \\
\hline & LoR3 & Unemployment rate (\%) & $\begin{array}{l}\text { Jobless people have difficulties to recover from flood } \\
\text { damages [55]. }\end{array}$ \\
\hline
\end{tabular}

\subsection{Indicator Development}

Before developing an integrated composite indicator for each component of vulnerability, the indictor set was first normalized using the Min-Max method in order to have values that are free from units and that lie in a range between 0 and 1 . However, because normalization follows certain rules, it is important to assess the functional relationship between the indicator and the vulnerability [56]. Thus, when the indicator $X j$ increases the vulnerability $(\mathrm{V})$, the normalized indicator is computed using the following Equation:

$$
X_{j}=\frac{x_{j}-\operatorname{Min}\left(x_{j}\right)}{\operatorname{Max}\left(x_{j}\right)-\operatorname{Min}\left(x_{j}\right)}
$$

When the indicators are related negatively to the vulnerability, the normalized value of the indicator is computed as follows:

$$
X_{j}=\frac{\operatorname{Max}\left(x_{j}\right)-x_{j}}{\operatorname{Max}\left(x_{j}\right)-\operatorname{Min}\left(x_{j}\right)}
$$

$X_{j}$ is the normalized value of the indicator $j$ of a vulnerability component $(\mathrm{E}, \mathrm{S}, \mathrm{LoR}) ; x_{j}$ is the value of the indicator $j ; \operatorname{Max}\left(x_{j}\right)$ and $\operatorname{Min}\left(x_{j}\right)$ are respectively the maximum and minimum values of the indicators $j$ of the vulnerability component. Table 2 gives the functional relationship between the indicators and the vulnerability.

\begin{tabular}{|c|c|c|c|}
\hline Vulnerability Components & $\mathbf{N}^{\circ}$ & Defined Indicators and Measuring Units & Functional Relationship \\
\hline \multirow{4}{*}{ Exposure (E) } & 1 & Population density (inhbts $/ \mathrm{km}^{2}$ ) & + \\
\hline & 2 & Altitude (m) & + \\
\hline & 3 & Flooded areas per sub-district (\%) & + \\
\hline & 4 & Vertical permeability $\left(\mathrm{m} / \mathrm{s}^{2}\right)$ & - \\
\hline \multirow{6}{*}{ Susceptibility (S) } & 1 & Vegetation cover per sub-district (\%) & - \\
\hline & 2 & Children under $5(\%)$ & + \\
\hline & 3 & Elderly above $65(\%)$ & + \\
\hline & 4 & Women (\%) & + \\
\hline & 5 & Waste collection (number of day/week) & - \\
\hline & 6 & Unplanned waste deposits (number) & + \\
\hline \multirow{3}{*}{ Lack of Resilience (LoR) } & 1 & Literacy rate $(\%)$ & - \\
\hline & 2 & People insured (\%) & - \\
\hline & 3 & Unemployment (\%) & + \\
\hline
\end{tabular}

Table 2. Functional relationship of vulnerability to urban flood.

Notes: (“+” = increasing vulnerability, " -" = decreasing vulnerability). 
Secondly, we assigned weights to the individual indicators by adopting an unequal weighting method, which is a statistical method proposed by [56]. According to these authors, weights are assumed to vary inversely with the variance over the region $(y)$ in the respective indicators of vulnerability. This leads to the following Equation:

$$
W_{j}=\frac{k}{\sqrt{\operatorname{var}\left(y_{j}\right)}}
$$

$k$ is a normalized constant such as:

$$
k=\left[\sum_{j=1}^{n} \frac{1}{\sqrt{\operatorname{var}\left(y_{j}\right)}}\right]^{-1}
$$

The normalized indicators were aggregated using the following Equation, according to their respective components $(E, S, L o R)$ :

$$
(E ; S ; L o R)=\sum_{j=1}^{k} W_{j} X_{j}
$$

With $(E, S, L o R)$ referring to the three components of vulnerability, $W_{j}$, the weight of the indicator $j$ and $X_{j}$, the normalized value of the indicator $j$.

Finally, we aggregated the three components $(E, S$ and $L o R)$ into the final composite indicator of social vulnerability using the Equation below [34,51].

$$
V=E\left(\frac{1}{2}\left(S_{i}+L o R_{i}\right)\right)
$$

$V$ refers to the vulnerability index of a given neighborhood, $S_{i}$ and $L o R_{i}$ are respectively the susceptibility and the Lack of Resilience of the sub-district $i$.

For classification purposes, simple ranking of the sub-districts would have been enough. However, for a meaningful characterization of the different stages of sustainability, suitable fractal classification from an assumed distribution is needed. Therefore, the quantile method, which is a predefined function of the ArcGIS 10.1 software, was used for the purpose. The values obtained were grouped into five classes, ranging from very low, low, medium, high, to very high [51].

\section{Results}

In this section, we present and describe the results obtained through the spatial analysis for all single and composite indicators used for the calculation of the final map of vulnerability. This description is compartmentalized by vulnerability components (exposure, susceptibility and lack of resilience).

\subsection{Exposure to Flood}

The exposure map obtained is a combination of four local indicators such as population density, elevation, percentage of flooded areas and soil vertical permeability. Those indicators were measured and spatially represented in Figure 3. The elevation map (Figure 3c) shows a southward altitude and ranges from $20 \mathrm{~m}$ to $91 \mathrm{~m}$ above sea level. The density map shows that the district of Cocody is compactly populated. The spatial distribution of the population does not show a side dependence and also did not depend on how large a sub-district is. The 447,000 inhabitants are sparsely distributed in the district of Cocody (Figure 3a). Many sub-districts have more than half of their area subject to flooding. Most of those sub-districts are located in the central and in the northern part of the main district (Figure $3 b$ ). The exposure map highlights five degrees of exposure which go from very low to very high exposure to flood. More than $38 \%$ of the sub-district of Cocody has an exposure to flooding that varies from high to very high. Most areas with very high exposure are located in the north part of the district where elevation and flooded areas appear high. 


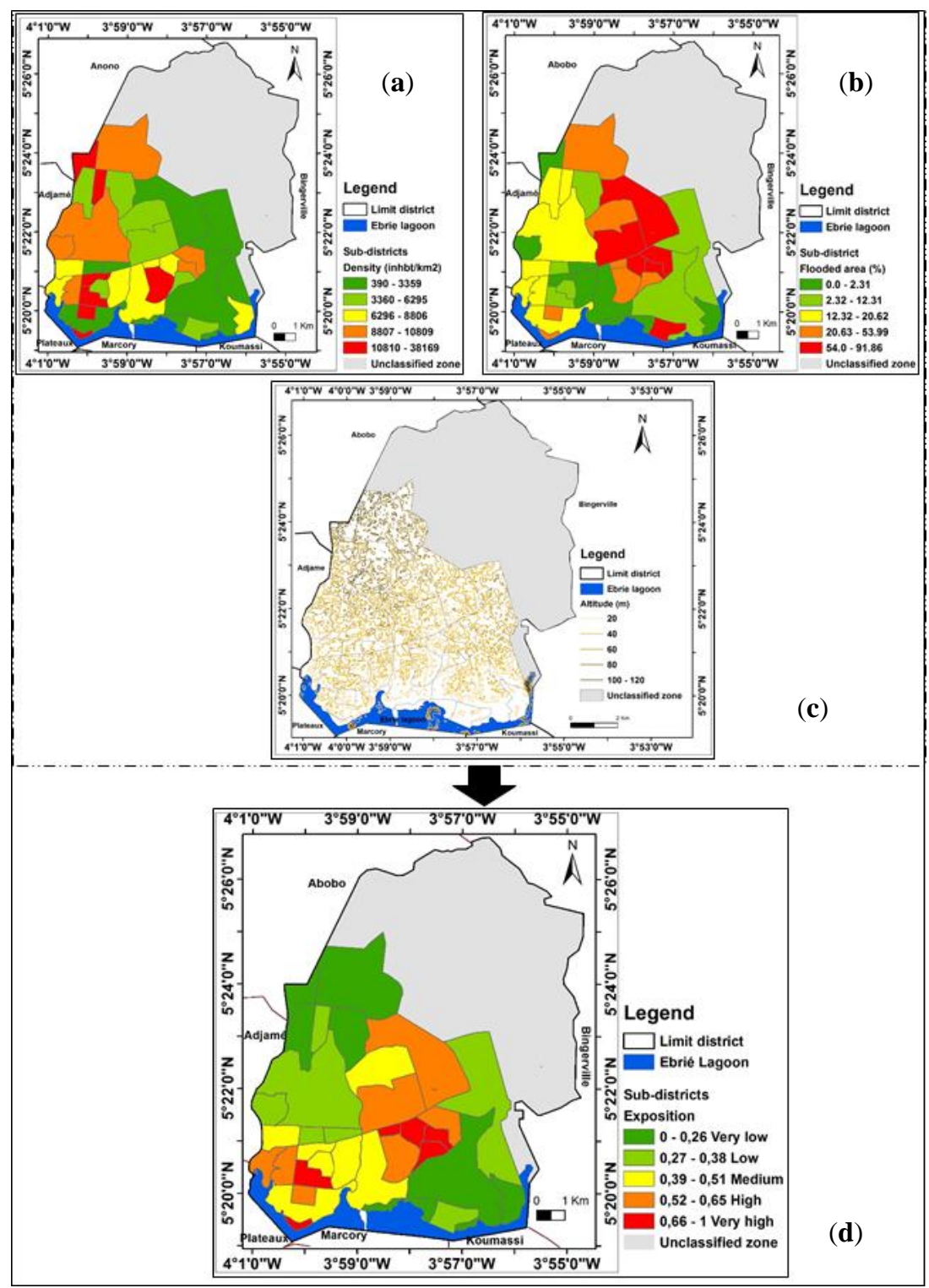

Figure 3. Exposure to flood: (a) Population density map; (b) Flooded area map; (c) Elevation map; (d) Exposure map.

\subsection{Susceptibility to Flood}

The susceptibility to flood map of the district of Cocody is presented in Figure 4. It is the result of the combination of six local indicators: vegetation cover, elderly, children, women, waste collection and unplanned waste deposit. The vegetation cover of the sub-districts that are located in the center and north-west of the district appears very low (Figure 4a). Concerning the spatial distribution of the elderly throughout the district, Figure $4 \mathrm{~b}$ shows that percentage of old people is very low in the district of Cocody and these people are more concentrated in the south of the district along the Ebrié lagoon, and particularly in the south-west, in sub-districts such as Blockauss, Cocody Centre, Ambassade and Val-doyen. Women are less represented in the district of Cocody. Only two sub-districts (Riviera Golf 1 , center-south and Aghien, northwest) show a high representation of females, significantly above $54 \%$ (Figure 4c). Children under five years are more concentrated in the southeast of the district of Cocody (Figure 4d). As presented in Figure 4e, there is very little regular waste collection in many sub-districts, particularly in the ones that are located in the south-east (e.g., M'Badon, M'Pouto, and Riviera 3-4-5). Concerning uncontrolled waste deposits, two sub-districts (Bonoumin and Angre) in particular have 
the highest number of unsafe waste deposits. As a result of the combination of the six local indicators described above, the district of Cocody presents hotspots of susceptibility in six sub-districts: Riviera Sogefiha, Copraci-Coprim, Riviera-Sideci, Palmeraie, Bounoumin and Blockauss. These sub-districts are mostly located in the center and north part of the district. More than $35 \%$ of the sub-districts have susceptibility ranging from high to very high and are sparsely distributed.

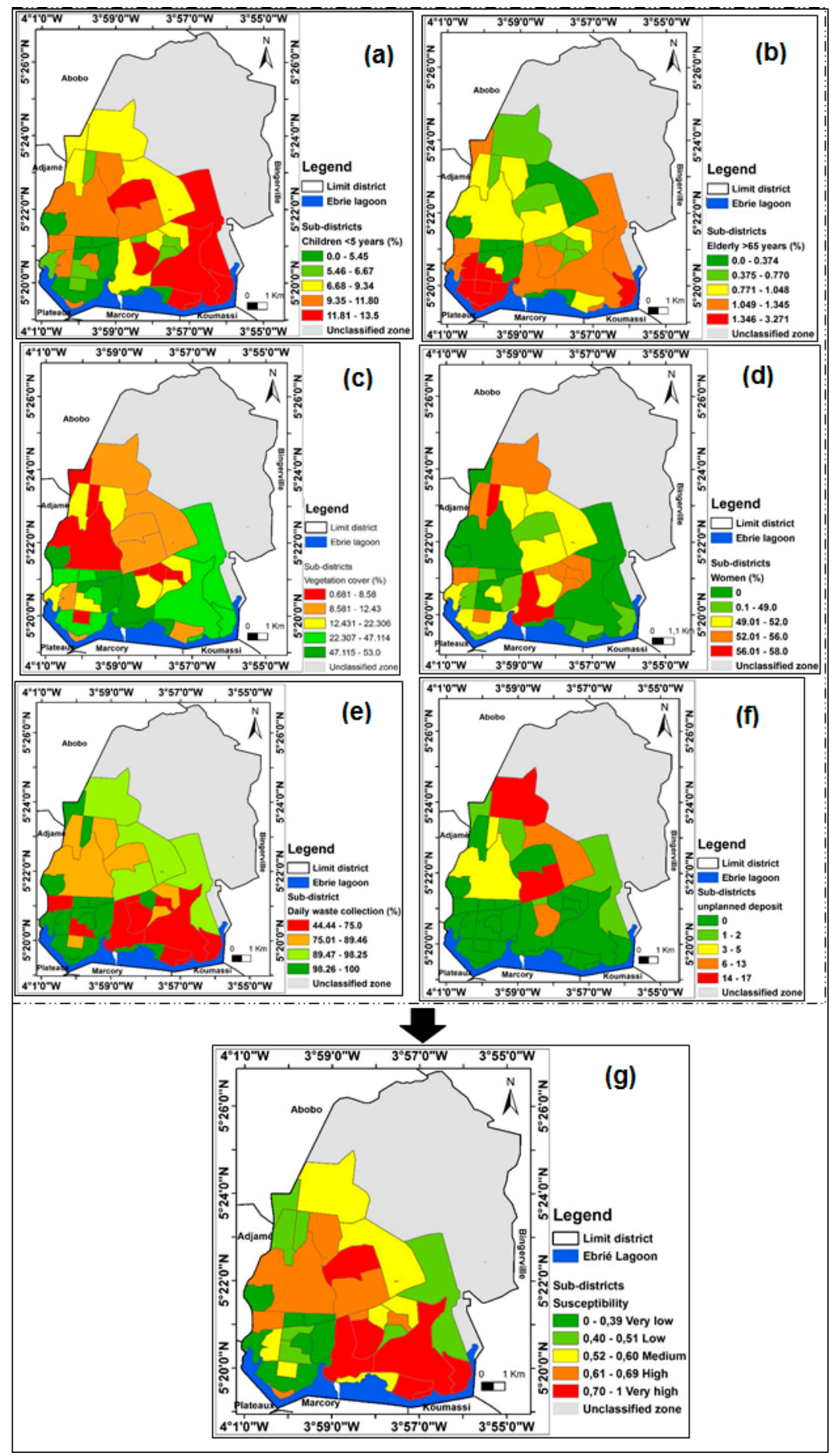

Figure 4. Susceptibility to flood: (a) Vegetation cover map; (b) Percentage of elderly map; (c) Percentage of women map; (d) Percentage of children under five map; (e) Daily waste collection frequency map; (f) Unplanned waste deposit map; (g) Susceptibility map. 


\subsection{Lack of Resilience to Flood}

For the calculation of lack of resilience, three local indicators were used: unemployment rate, literacy rate and insurance. Unemployed people, who represent the group with least capacity to recover from flood damages without external help, are, in general, sparsely distributed across the district of Cocody. However, in the south-east part of the district, there is an exceptionally high concentration of jobless people (Figure 5a). The percentage of unemployed people appears to be high in Cocody with more than $80 \%$ of the sub-districts having more than $60 \%$ unemployment. The literacy rate per sub-district appears high as well. All of the sub-districts have a literacy rate greater than $60 \%$. The lower literacy rates are mostly located in the north-west (Figure 5b). Most people living in the district of Cocody are not insured. The insured people (Figure 5c) are sparsely distributed in the municipality. They are mainly concentrated in the center-south of the district. The combination of the three local indicators gives the lack of resilience map of the district of Cocody. People lacking capacity to face flooding are concentrated in the north and north-west of the district of Cocody, and there are very high values for some sub-districts in the south such as M'Pouto, M'Badon and Val Doyen. The lack of resilience of more than $38 \%$ of the sub-district varies from high to very high.

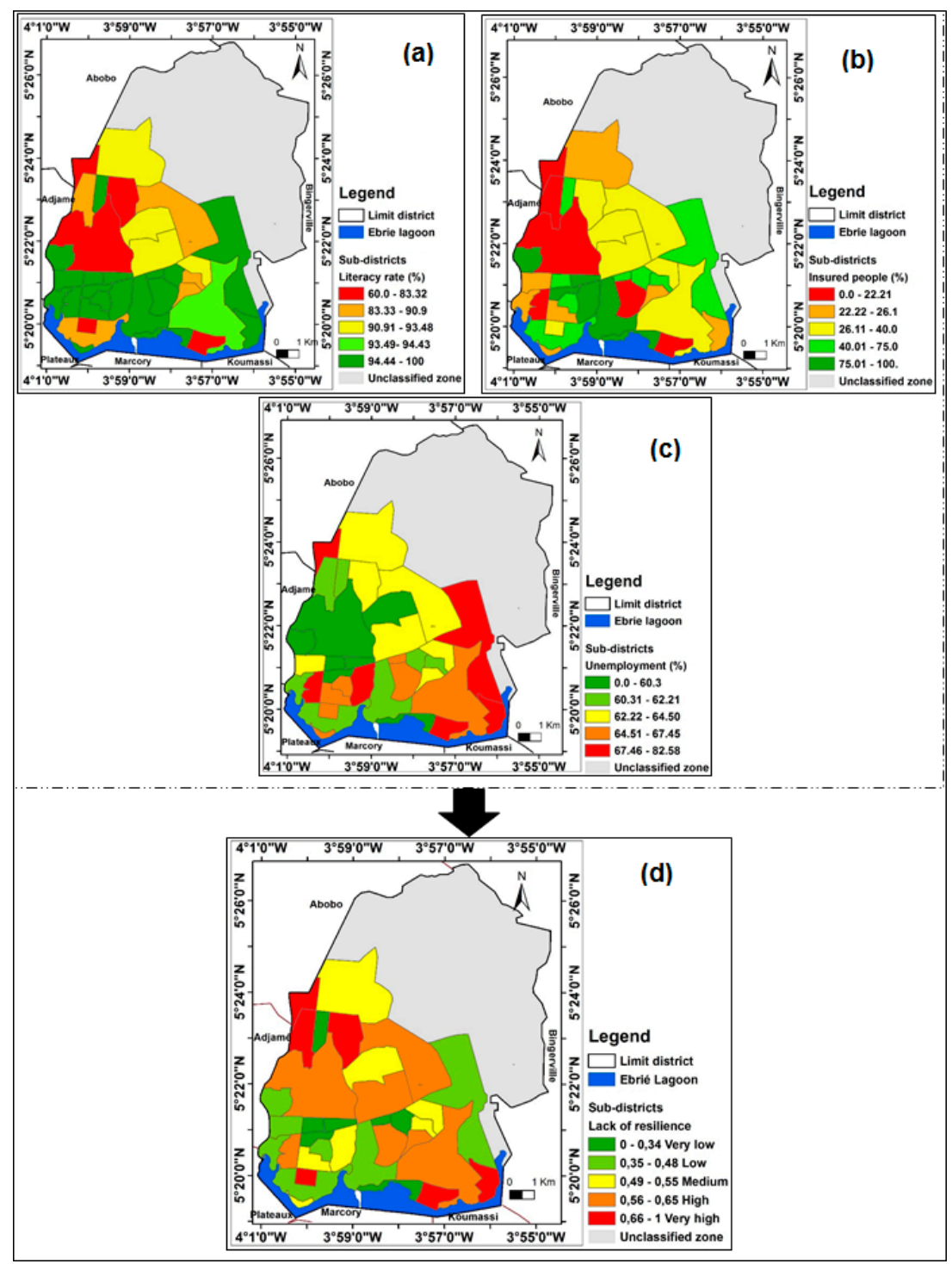

Figure 5. Lack of resilience to flood: (a) Unemployment rate map; (b) Literacy rate map; (c) Insured people map; (d) Lack of resilience map. 


\subsection{Vulnerability to Flood}

The spatial distribution of vulnerable areas of the district of Cocody is presented in Figure 6. As a result of the combination of the three composite indicators of the vulnerability components (exposure, susceptibility and lack of resilience), the highest vulnerability to flood affects the north-east (Riviera Golf 1, Riviera Sogefiha, Riviera Sideci and Capraci-Coprim) and the south-west (Blockauss). More than $38 \%$ of the sub-districts have a vulnerability index varying from high to very high. The lowest vulnerabilities are sparsely distributed throughout the district of Cocody. The sub-districts with lowest vulnerability are CHU, Cite des Arts, Gendarmerie, Cite des Cadres, Sideci-zoo, and Riviera-EECI.

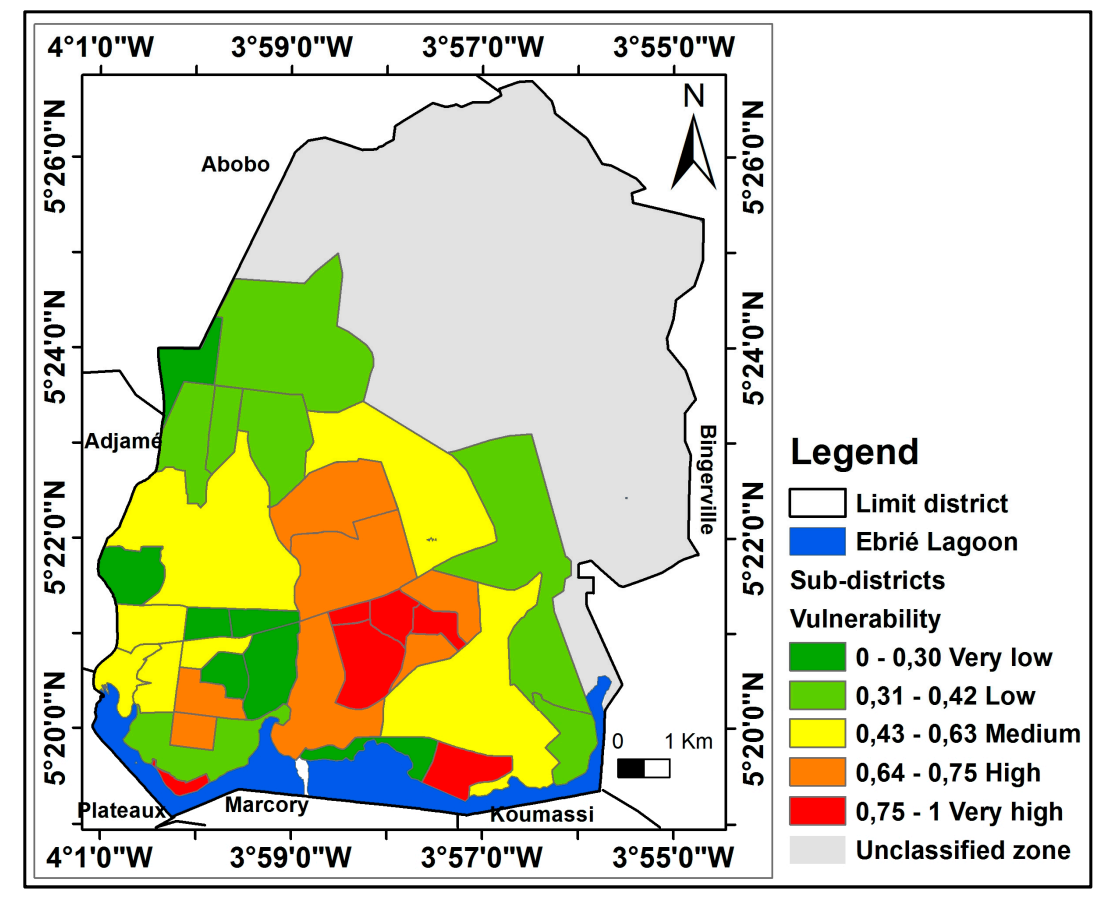

Figure 6. Map of vulnerability to flood.

Table 3 was created with "SPSS Statistics" by computing a correlation and significance test (2-tailed at $1 \%$ ). It gives the weight of each composite indicator on the model's output.

It appears from the analysis of the table that many indicators are highly correlated with vulnerability. Concerning exposure, vertical permeability is significantly (at $1 \%$ ) correlated with the vulnerability. The susceptibility's indicators that are significantly correlated with the vulnerability are elderly (at $1 \%$ ) and percentage of women (5\%). For lack of resilience, unemployment is significantly correlated at $5 \%(p=0.02)$ with the vulnerability. Among the vulnerability components, exposure and susceptibility to flood are significantly correlated (at 1\%) with vulnerability. The indicators aforementioned have, therefore, the highest influence on the model's output. 
Table 3. Correlation of each component with the vulnerability.

\begin{tabular}{|c|c|c|c|c|c|c|c|c|c|c|c|c|c|c|c|c|c|}
\hline E1 & 1 & & & & & & & & & & & & & & & & \\
\hline E2 & 0.05 & 1 & & & & & & & & & & & & & & & \\
\hline E3 & 0.00 & 0.17 & 1 & & & & & & & & & & & & & & \\
\hline E4 & 0.22 & $-0.35 *$ & 0.06 & 1 & & & & & & & & & & & & & \\
\hline $\mathbf{E}$ & $0.62 * *$ & $0.42^{*}$ & $0.59 * *$ & $0.45^{* *}$ & 1 & & & & & & & & & & & & \\
\hline S1 & -0.11 & 0.11 & 0.01 & $-0.46^{* *}$ & -0.21 & 1 & & & & & & & & & & & \\
\hline S2 & -0.12 & 0.26 & $-0.36^{*}$ & -0.30 & -0.25 & -0.06 & 1 & & & & & & & & & & \\
\hline S3 & $0.39 *$ & -0.17 & $0.57 * *$ & 0.02 & $0.39 *$ & -0.03 & -0.05 & 1 & & & & & & & & & \\
\hline S4 & 0.04 & 0.22 & 0.29 & -0.09 & 0.22 & -0.17 & 0.07 & 0.17 & 1 & & & & & & & & \\
\hline S5 & 0.05 & 0.23 & 0.07 & -0.28 & 0.03 & 0.34 * & -0.13 & 0.09 & -0.11 & 1 & & & & & & & \\
\hline S6 & -0.05 & -0.37 * & 0.27 & 0.10 & -0.02 & 0.09 & -0.21 & 0.22 & 0.07 & -0.05 & 1 & & & & & & \\
\hline $\mathrm{S}$ & 0.15 & 0.10 & 0.36 * & -0.40 * & 0.10 & $0.65^{* *}$ & -0.02 & $0.58^{* *}$ & 0.08 & $0.70^{* *}$ & 0.23 & 1 & & & & & \\
\hline LoR1 & -0.20 & $-0.47^{* *}$ & 0.17 & 0.01 & -0.24 & 0.05 & -0.19 & $0.36 *$ & -0.15 & 0.08 & 0.12 & 0.22 & 1 & & & & \\
\hline LoR2 & 0.00 & -0.09 & 0.30 & -0.03 & 0.09 & 0.32 & -0.22 & $0.45^{* *}$ & -0.18 & $0.42 *$ & 0.22 & $0.58^{* *}$ & 0.43 * & 1 & & & \\
\hline LoR3 & 0.08 & 0.12 & -0.24 & -0.22 & -0.12 & 0.29 & 0.13 & -0.12 & -0.04 & 0.05 & -0.03 & 0.12 & -0.03 & -0.19 & 1 & & \\
\hline LoR & -0.06 & -0.24 & 0.13 & -0.13 & -0.14 & 0.36 * & -0.15 & $0.37^{*}$ & -0.20 & 0.30 & 0.17 & $0.50^{* *}$ & $0.76^{* *}$ & $0.67^{* *}$ & 0.42 * & 1 & \\
\hline \multirow{3}{*}{ V (sig) } & $0.52 * *$ & 0.31 & $0.64^{* *}$ & 0.08 & $0.75 * *$ & 0.26 & -0.19 & $0.66^{* *}$ & 0.184 & $0.46^{* *}$ & 0.17 & $0.72^{* *}$ & 0.04 & $0.48^{* *}$ & 0.01 & 0.29 & 1 \\
\hline & 0.00 & 0.07 & 0.00 & 0.66 & 0.00 & 0.13 & 0.28 & 0.00 & 0.30 & 0.01 & 0.34 & 0.00 & 0.80 & 0.00 & 0.95 & 0.10 & \\
\hline & E1 & E2 & E3 & E4 & E & S1 & S2 & S3 & S4 & S5 & S6 & $S$ & LoR1 & LoR2 & LoR3 & LoR & V \\
\hline
\end{tabular}

Note: Pearson correlation $\left({ }^{* *}, p<0.01{ }^{*}, p<0.05\right)$. 


\section{Discussion}

Designing a proper management strategy to tackle flooding in urban areas requires integrated approaches which take into account a broader set of local indicators that consider the social, physical and ecological dimension of vulnerability [57]. Our study aimed to assess the social vulnerability of urban populations to flooding using the MOVE framework. As with most conceptual frameworks, it required consideration of a broader set of local indicators that act on population vulnerability [53]. The MOVE framework served as a guidance tool for the selection of indicators. For the sake of the research, it has to be highlighted that this is a purely statistical validation of the indicators and has not been confirmed by external stakeholders. In fact, though the vulnerability of the district of Cocody to flood is expected to be low compared to other districts in Abidjan due to the relatively high social standing characteristic (a prestigious district where most government officials reside) of the district, it represented a relevant case to investigate, as it records the highest number of flood-affected people [25]. Thus, an assessment of the relevant local indicators that influenced vulnerability to flood in urban areas was important to guide decision making processes [40,58]. The approach not only provides information on the neighborhoods where intervention will be most requested, but also indicates which factors need to be prioritized to effectively reduce existing susceptibility and increase resilience to flood exposure. Thus, based on this framework, several neighborhoods of Cocody appear to be flood vulnerability hot spots. The highest vulnerabilities are in areas such as Blockauss, Palmeraie, Riviera-Sideci, Copraci-Coprim, Attoban and Riviera-SOGEFIHA. Except for the village of Blockauss, sub-districts with very high vulnerability are generally medium social standing sub-districts. Also, some low social standing sub-districts (M'Badon) with "lack of resilience" appear less vulnerable than some so-called prestigious sub-districts, such as Canebiere. This situation could be explained by the fact that vulnerability was not correlated to the lack of resilience, but rather strongly correlated with susceptibility and exposure. Moreover, due to data availability and lack of reliable data, some relevant indicators of lack of resilience such as disaster aids, medical care, timely evacuation mechanism, were not taken into account in this study. Those variables are usually services provided by the public sector, and help to strengthen individual adaptive capacity. Thus, reducing social vulnerability is relatively correlated to providing social services and public assistance after a disaster [59]. However, our study does not offer this prime example. When looking at the study done by [51], one can realize that some sub-districts with high "lack of vulnerability" came out with low vulnerability. This result could be explained by the aggregation process [48]. The sub-district Palmeraie appears with a medium vulnerability. However, it is one of the most impacted sub-districts with more than half of the area being at flood risk. This may be explained by the fact that vulnerability is a set of multiple stressors [11] that act together to determine the vulnerability of an area. These stressors include the geographical location, exposure of population and infrastructure, socio-economic and cultural conditions, political and institutional structures as well as coping and adaptive capacity that differentiate the impacts on people and the human system [22]. That means also that though an area may be highly-exposed to a hazard, it can be less vulnerable if it has adequate means to adapt to the phenomenon. Vulnerability is therefore not a matter of only exposure, but rather a combination of exposure with local socio-economic factors [48]. However, as more than half of the inhabited areas of Cocody are known as subject to flooding areas, authorities should consider providing more adequate drainage systems in those districts to help channel the excess water flow. Indeed, during the geographical survey, observations made on the drainage infrastructures have highlighted that many of them were either damaged or obstructed and therefore were not working properly. Susceptibility takes into account weaker people of the social layer, as well as land use (vegetation cover) and waste management. In the district of Cocody, the sub-districts with weaker people are located outside zones. This is important information that could help emergency responses in case a disaster strikes the district. Concerning vegetation cover, the results show that this indicator is significantly correlated with vulnerability. It is therefore an Important factor, due to its influence on rain water runoff, which needs to be examined carefully [60]. Vegetation cover is thus necessary in the areas that show high exposure (flooded areas, high population 
density, and hillside). Poor waste management is known to highly contribute to urban flood hazard. Therefore, it increases risk. Many sub-districts record numerous areas of unplanned waste deposit. Moreover, waste collection is not frequent in many sub-districts. Most of these sub-districts appear to be vulnerable to flood. Thus, efforts should be undertaken to avoid flood-related health issues in those areas. Furthermore, as urban flooding is usually periodic (meaning during rainy seasons [23]), waste collection should be amplified during the rainy season to prevent waste from choking the existing drainage systems and overflowing into households, leading to health-related diseases such as cholera and typhoid.

The MOVE framework can serve as a first basis for decision-making as it facilitated the selection and the combination of several local indicators, which constituted a real advantage. Thus, it helps reduce the complexity of vulnerability to a single index value, and permits grasping the current situation at one glance. It can therefore be used for communication purposes in risk management strategy. The MOVE framework also allowed a better understanding of each indicator's contribution to local urban flood vulnerability based on their weight in the model output. The results indicated that the MOVE framework can be used in an African context by contextualizing the vulnerability to local levels. It has even helped to evaluate vulnerability in other regions of the world different from Europe, such as Colombia [49]. Findings from this research are particularly salient for municipal authorities. As an example, for the planning of an emergency intervention strategy, it can help indicate where people are most exposed to flood and where the most vulnerable people to flood are. That can facilitate timely response strategies during a hazard by pointing towards areas that should be prioritized. Thus, those vulnerable areas should be provided more open spaces, as they can serve as safe venues for various kinds of emergency services such as provision of relief supplies as well as for setting up a security command center and medical aid stations [61,62].

However, the MOVE framework came with some challenges. It is firstly important to mention that an indicator expresses a certain fact but should not be taken with the integrity of reality [63]. Also, the modeling approach is not spatially explicit [49]. The approach used, and the fact that indicators were reported at a sub-district level, neglect the heterogeneous and continuous vulnerability within a sub-district and across all sub-districts of the district. This creates artificial boundaries and considers a sub-district as a closed block with no interaction with other sub-districts. That is not, in reality, true. Thus, a more realistic vulnerability mapping calls for spatially explicit modeling approaches, which enable a continuous and heterogeneous vulnerability within and among sub-districts. For doing that, vulnerability should be investigated at the household level rather than sub-district level. This would avoid delimitating an area; however, it would call for a huge sample size.

\section{Conclusions}

The social vulnerability of the district of Cocody (in Abidjan, Côte d'Ivoire) to flood has been assessed with local indicators. Using sub-districts as the spatial reporting unit, the study aggregated the local indicators to a single composite index that enable spatial vulnerability representation at district level. These indicators were composed of various socio-economics and environmental factors. The MOVE theoretical framework, although designed for western European countries, was successfully used in this Sub-Saharan African context. It has helped to spatially differentiate vulnerable sub-districts to urban flood. The results showed that several districts are flood vulnerability hot spots. Also, factors influencing vulnerability to urban flooding have been highlighted. They suggest that the MOVE theoretical framework is a promising tool for vulnerability assessment in local context. Moreover, though designed to improve vulnerability assessment in Europe, the model could be applied and contextualized in any area of the world using local indicators and can lead to policy relevant results. The results are easily understandable and transferable to the local decision-making context. Findings from this study imply that future research should consider assessing vulnerability at household level using local indicators. That will help integrate more relevant and first-hand data such as household income and size. Research dealing with vulnerability assessment should also consider taking into 
account the context of human impacts and fatalities by integrating multiple variables in disaster management plans, such as early warning system, temporary shelter, proximity of hospital and medical care.

Acknowledgments: This research received no specific grant from any funding agency in the public, commercial, or not-for-profit sectors. The authors attest that no funds were received for covering the costs to publish in the journal. The authors would like to thank the Université Félix Houphouët Boigny, Abidjan, Côte d'Ivoire (UFHB) from which this work is derived. They acknowledge the collaboration of the Centre Suisse de Recherches Scientifiques en Côte d'Ivoire (CSRS). We are also grateful to the collaboration of the West African Science Service Center on Climate Change and adapted Land Used (WASCAL, Abidjan, Côte d'Ivoire). Finally, the authors would like to express their gratitude to the population and authorities of Cocody and to thank them for their collaboration in data collection.

Author Contributions: Malan Ketcha Armand Kablan and Kouassi Dongo conceptualized and designed the research. Malan Ketcha Armand Kablan collected data from various sources, performed the assessment and drafted the original manuscript. Kouassi Dongo and Mamadou Coulibaly provided skills development, comments and suggestions during data generation, analysis, and results interpretation. All authors helped improve the different versions of the manuscript. They also read and approved its final draft.

Conflicts of Interest: The authors declare no conflict of interest.

\section{References}

1. Adetunji, M.; Oyeleye, O. Evaluation of the causes and effects of flood in Apete, Ido Local Government Area, Oyo State, Nigeria. Civ. Environ. Res. 2013, 3, 19-26.

2. Nasiri, H.; Shahmohammadi-kalalagh, S. Flood vulnerability index as a knowledge base for flood risk assessment in urban area. J. Novel Appl. Sci. 2013, 2, 269-272.

3. Intergovernmental Panel on Climate Change. Summary for policy makers. In Climate Change 2014: Impacts, Adaptation, and Vulnerability; Field, C.B., Barros, V.R., Dokken, D.J., Mach, K.J., Mastrandrea, M.D., Bilir, T.E., Chatterjee, M., Ebi, K.L., Estrada, Y.O., Genova, R.C., et al., Eds.; Cambridge University Press: Cambridge, UK; New York, NY, USA, 2014; pp. 1-32.

4. Tingsanchali, T. Urban flood disaster management. Procedia Eng. 2012, 32, 25-37. [CrossRef]

5. Balica, S.F.; Wright, N.G.; van der Meulen, F. A flood vulnerability index for coastal cities and its use in assessing climate change impacts. Nat. Hazards 2012, 64, 73-105. [CrossRef]

6. Sané, O.D.; Gaye, A.T.; Diakhaté, M.; Aziadekey, M. Social vulnerability assessment to flood in Medina Gounass Dakar. J. Geogr. Inf. Syst. 2015, 7, 415-429. [CrossRef]

7. Danumah, J.H.; Odai, S.N.; Saley, B.M.; Szarzynski, J.; Thiel, M.; Kwaku, A.; Kouame, F.K.; Akpa, L.Y. Flood risk assessment and mapping in Abidjan district using multi-criteria analysis (ahp) model and geoinformation techniques, (cote d'ivoire). Geoenviron. Disasters 2016, 3, 10. [CrossRef]

8. Xue, K.; Ajmera, B.; Tiwari, B.; Hu, Y. Effect of long duration rainstorm on stability of red-clay slopes. Geoenviron. Disasters 2016, 3, 12. [CrossRef]

9. Balica, S.F.; Douben, N.; Wright, N.G. Flood vulnerability indices at varying spatial scales. Water Sci. Technol. 2009, 60, 2571-2580. [CrossRef] [PubMed]

10. Cançado, V.; Brasil, L.; Nascimento, N.; Guerra, A. Flood risk assessment in an urban area: Measuring hazard and vulnerability the manhuaçu case-study. In Proceedings of the 11th International Conference on Urban Damage, Edinburgh, Scotland, UK, 31 August-5 September 2008; pp. 1-10.

11. Barroca, B.; Bernardara, P.; Mouchel, J.M.; Hubert, G. Indicators for identification of urban flooding vulnerability. Nat. Hazards Earth Syst. Sci. 2006, 6, 553-561. [CrossRef]

12. Depietri, Y.; Renaud, F.G.; Kallis, G. Heat waves and floods in urban areas: A policy-oriented review of ecosystem services. Sustain. Sci. 2012, 7, 95-107. [CrossRef]

13. United Nations Office for Disaster Risk Reduction (UNISDR). Guidelines for Reducing Flood Losses; United Nations-Headquarters (UN): New York, NY, USA, 2002; p. 79.

14. Parkinson, J. Urban drainage in developing countries-Challenges and opportunities. Waterlines 2002, 20, 1-5. [CrossRef]

15. Zhou, Q. A review of sustainable urban drainage systems considering the climate change and urbanization impacts. Water 2014, 6, 976-992. [CrossRef] 
16. Lamond, J.; Bhattacharya, N.; Bloch, R. The role of solid waste management as a response to urban flood risk in developing countries, a case study analysis. In Flood Recovery Innovation and Response; WIT Press: Southampton, UK, 2012; pp. 193-205.

17. UN-Habitat. The State of African Cities 2008: A Framework for Addressing Urban Challenges in Africa; UN-HABITAT: Nairobi, Kenya, 2008; p. 220.

18. Intergovernmental Panel on Climate Change. Climate Change 2007: The Physical Science Basis. Contribution of Working Group I to the Fourth Assessment Report of the Intergovernmental Panel on Climate Change; Cambridge University Press: Cambridge, UK; New York, NY, USA, 2007; p. 996.

19. Intergovernmental Panel on Climate Change. Managing the Risks of Extreme Events and Disasters to Advance Climate Change Adaptation -Summary for Policymakers; IPCC: New York, NY, USA, 2012; p. 582.

20. World Health Organization. WMO Disaster Risk Reduction Work Plan (2012-2015) Updated as of: 21 March 2014; WHO: Geneva, Switzerland, 2015; p. 12.

21. Okayo, J.; Odera, P.; Omuterema, S. Socio-economic characteristics of the community that determine ability to uptake precautionary measures to mitigate flood disaster in Kano Plains, Kisumu County, Kenya. Geoenviron. Disasters 2015, 2, 26. [CrossRef]

22. Adelekan, I.O. Vulnerability assessment of an urban flood in Nigeria: Abeokuta flood 2007. Nat. Hazards 2011, 56, 215-231. [CrossRef]

23. Tschakert, P.; Sagoe, R.; Ofori-Darko, G.; Codjoe, S.N. Floods in the Sahel: An analysis of anomalies, memory, and anticipatory learning. Clim. Chang. 2010, 103, 471-502. [CrossRef]

24. Samimi, C.; Fink, A.H.; Paeth, H. The 2007 flood in the Sahel: Causes, characteristics and its presentation in the media and fews net. Nat. Hazards Earth Syst. Sci. 2012, 12, 313-325. [CrossRef]

25. Office for the Coordination of Humanitarian Affairs. Côte d'Ivoire: Zones à Risques d'Inondations et de Choléra; OCHA: Abidjan, Côte d'Ivoire, 2014.

26. Dongo, K.; Cissé, G.; Biémi, J. Étude des inondations par débordement de réseau dans les milieux défavorisés d'abidjan; côte d'ivoire. In Proceedings of the 13th IWRA World Water Congress, Global Changes and Water Resources, Montpelier, France, 1-4 September 2008; pp. 1-12.

27. Hauhouot, C. Analyse du risque pluvial dans les quartiers précaires d'abidjan. Etude de cas à attécoubé. Geo-Eco-Trop 2008, 32, 75-82.

28. Mendel, G. Climate Change, Urban Flooding and the Right of Urban Poor in African: Key Findings from Six African Cities; Action Aid International: London, UK; Johannesburg, South Africa, 2006.

29. De Leon, J.C.V. Vulnerability: A Conceptual and Methodological Review; United Nations University, Institute for Environment and Human Security: Bonn, Germany, 2006; p. 84.

30. Birkmann, J. Risk and vulnerability indicators at different scales: Applicability, usefulness and policy implications. Environ. Hazards 2007, 7, 20-31. [CrossRef]

31. Füssel, H.-M. Review and Quantitative Analysis of Indices of Climate Change Exposure, Adaptive Capacity, Sensitivity, and Impacts; LACER-LACEA: Bogotá, Colombia, 2010; p. 34.

32. Intergovernmental Panel on Climate Change. Summary for policy makers. In Climate Change 2014: Impacts, Adaptation, and Vulnerability. Part A: Global and Sectoral Aspects. Contribution of Working Group II to the Fifth Assessment Report of the Intergovernmental Panel on Climate Change; Intergouvernemental Panel on Climate Change: Geneva, Switzerland; Cambridge University Press: Cambridge, UK; New York, NY, USA, 2014; pp. 1-32.

33. United Nations Development Programme (UNDP). Sustaining Human Progress: Reducing Vulnerabilities and Building Resilience; United Nations Development Programme: New York, NY, USA, 2014; p. 239.

34. Welle, T.; Depietri, Y.; Angignard, M.; Birkmann, J.; Renaud, F.; Greiving, S. Vulnerability assessment to heat waves, floods, and earthquakes using the move framework: Test case cologne, germany. In Assessment of Vulnerability to Natural Hazards; Birkmann, J., Kienberger, S., Alexander, D.E., Eds.; Elsevier: Bonn, Germany, 2014; pp. 91-124.

35. Kuhlicke, C.; Scolobig, A.; Tapsell, S.; Steinführer, A.; de Marchi, B. Contextualizing social vulnerability: Findings from case studies across Europe. Nat. Hazards 2011, 58, 789-810. [CrossRef]

36. Ciurean, R.L.; Schröter, D. Conceptual Frameworks of Vulnerability Assessments for Natural Disasters Reduction; Intech: Rijeka, Croatia, 2013; pp. 3-32.

37. Cutter, S.L.; Ash, K.D.; Emrich, C.T. The geographies of community disaster resilience. Glob. Environ. Chang. 2014, 29, 65-77. [CrossRef] 
38. Birkmann, J. Measuring vulnerability to promote disaster-resilient societies: Conceptual frameworks and definition. In Measuring Vulnerability to Natural Hazards: Towards Disaster Resilient Societies; Birkmann, J., Ed.; United Nation Press: New York, NY, USA, 2006; pp. 7-54.

39. Turner, B.L.; Kasperson, R.E.; Matson, P.A.; McCarthy, J.J.; Corell, R.W.; Christensen, L.; Eckley, N.; Kasperson, J.X.; Luers, A.; Martello, M.L.; et al. A framework for vulnerability analysis in sustainability science. Proc. Natl. Acad. Sci. USA 2003, 100, 8074-8079. [CrossRef] [PubMed]

40. Birkmann, J.; Cardona, O.D.; Carreño, M.L.; Barbat, A.H.; Pelling, M.; Schneiderbauer, S.; Kienberger, S.; Keiler, M.; Alexander, D.; Zeil, P.; et al. Framing vulnerability, risk and societal responses: The move framework. Nat. Hazards 2013, 67, 193-211. [CrossRef]

41. European Union. Final Report Summary-Move (Methods for the Improvement of Vulnerability Assessment in Europe); European Commission: Florence, Italy, 2015; pp. 1-12.

42. RGPH. Recensement Général de la Population et de l'Habitat 2014: Principaux Résultats Préliminaires; Institut National de la Statistique: Abidjan, Côte d'Ivoire, 2014; p. 26.

43. Lucio, P.S.; Carlos, L.; Molion, B.; Elisa, C.; Valadão, D.A.; Conde, F.C.; Ramos, A.M.; Luciene, M.; Melo, D.D. Dynamical outlines of the rainfall variability and the itcz role over the west sahel. Atmostpheric Clim. Sci. 2012, 2012, 337-350. [CrossRef]

44. Sultan, B.; Janicot, S. Abrupt shift of the itcz over West Africa and intra-seasonal variability. Geophys. Res. Lett. 2000, 27, 3353-3356. [CrossRef]

45. Statistics Canada. Survey Methods and Practices; Ministry of Industry: Ottawa, ON, Canada, 2010; p. 408.

46. European Union. Final report summary-Move (methods for the improvement of vulnerability assessment in Europe). Res. Innov. 2015, 1-12.

47. United Nations Environment Programme. Assessing Human Vulnerability to Environmental Change: Concepts, Issues, Methods and Case Studies; United Nations Environment Programme: Nairobi, Kenya, 2002; p. 68.

48. Rygel, L.; O'sullivan, D.; Yarnal, B. A method for constructing a social vulnerability index: An application to hurricane storm surges in a developed country. Mitig. Adapt. Strateg. Glob. Chang. 2006, 11, 741-764. [CrossRef]

49. Hagenlocher, M.; Delmelle, E.; Casas, I.; Kienberger, S. Assessing socioeconomic vulnerability to dengue fever in Cali, Colombia: Statistical vs expert-based modeling. Int. J. Health Geogr. 2013, 12, 36. [CrossRef] [PubMed]

50. Kumar, P.; Reddy, K.; Reddy, C. Assessment of vulnerability and impact of climate change on crop production in Krishna River Basin of Andhra Pradesh. Int. J. Curr. Agric. Res. 2014, 3, 62-66.

51. Depietri, Y.; Welle, T.; Renaud, F.G. Social vulnerability assessment of the cologne urban area (Germany) to heat waves: Links to ecosystem services. Int. J. Disaster Risk Reduct. 2013, 6, 98-117. [CrossRef]

52. Damm, M. Mapping Social-Ecological Vulnerability to Flooding: A Sub-National Approach for Germany. Master's Thesis, United Nations University, Bonn, Germany, 2009.

53. Müller, A.; Reiter, J.; Weiland, U. Assessment of urban vulnerability towards floods using an indicator-based approach-A case study for Santiago de Chile. Nat. Hazards Earth Syst. Sci. 2011, 11, 2107-2123. [CrossRef]

54. Luong, A.T. Évaluation des Risques d'Inondations Dans le Bassin du Fleuve Huong, Province de thua Thien hue, Centre du Vietnam. Ph.D. Thesis, Université du Québec, Montreal, QC, Canada, 2012.

55. Dwyer, A.; Zoppou, C.; Nielsen, O.; Day, S.; Roberts, S. Quantifying social vulnerability: A methodology for identifying those at risk to natural hazards. Geosci. Aust. Rec. 2004, 14, 1-100.

56. Lyengar, N.S.; Sudarshan, P.A. Method of classifying regions from multivariate data. Econ. Polit. Wkly 1982, 18, 2048-2052.

57. Rufat, S.; Tate, E.; Burton, C.G.; Maroof, A.S. Social vulnerability to floods: Review of case studies and implications for measurement. Int. J. Disaster Risk Reduct. 2015, 14, 470-486. [CrossRef]

58. Hasanzadeh Nafari, R.; Ngo, T.; Mendis, P. An assessment of the effectiveness of tree-based models for multi-variate flood damage assessment in Australia. Water 2016, 8, 282. [CrossRef]

59. Flanagan, B.E.; Gregory, E.W.; Hallisey, E.J.; Heitgerd, J.L.; Lewis, B. A social vulnerability index for disaster management a social vulnerability index for disaster management. J. Homeland Secur. Emerg. Manag. 2011, $8,1-22$.

60. Halounova, L.; Holubec, V. Assessment of flood with regards to land cover changes. Procedia Econ. Finan. 2014, 18, 940-947. [CrossRef] 
61. Fan, L.; Xue, S.; Liu, G. Patterns and its disaster shelter of urban green space: Empirical evidence from Jiaozuo City, China. Afr. J. Agric. Res. 2012, 7, 1184-1191.

62. United Nations Office for Disaster Risk Reduction. Space and Disaster Risk Reduction: Planning for Resilient Human Settlements: Perspectives towards the Fourth Session of the Global Platform for Disaster Risk Reduction; United Nations Office on Disaster Risk Reduction (UNISDR): Geneva, Switzerland, 2013.

63. Ademe. Indicateurs de Vulnérabilité d'un Territoire au Changement Climatique; Collectivités Territoriales: New Caledonia, France, 2013; pp. 1-64.

(C) 2017 by the authors. Licensee MDPI, Basel, Switzerland. This article is an open access article distributed under the terms and conditions of the Creative Commons Attribution (CC BY) license (http:/ / creativecommons.org/licenses/by/4.0/). 